\title{
PERCEPÇÃO DE AMOSTRA POPULACIONAL SOBRE GUARDA RESPONSÁVEL
}

\author{
PERCEPTION OF POPULATION ABOUT RESPONSIBLE OWNERSHIP
}

\author{
B. F. IZOLA ${ }^{1 *}$, M. B. D. OLIVARI ${ }^{1}$, F. G. FONSATTI ${ }^{1}$, J. H. B. TOSCANO ${ }^{1}$, J. L. BENEVENUTE. ${ }^{2}$, \\ E. M. N. PAULA 2 , A. P. R. GRISOLIO ${ }^{2}$, A. A. B. CARVALHO ${ }^{3}$
}

\section{RESUMO}

A presença dos animais de companhia domésticos nas famílias são cada vez mais frequentes e a convivência mais estreita. $\mathrm{O}$ objetivo desse trabalho foi avaliar a percepção de uma amostra da população sobre guarda responsável. Os dados foram obtidos por meio de um questionário online, semi-estruturado, com 18 questões sobre o perfil do proprietário, animais e hábitos relacionados à guarda responsável; durante o mês de setembro de 2015. O software utilizado para coleta e tabulação de dados foi o formulário do Google Drive. As respostas foram analisadas por estatística descritiva. Participaram da pesquisa 235 pessoas, sendo 76,6\% do gênero feminino, com faixa etária entre 14 e 70 anos, sendo que $98,3 \%$ tinham o $2^{\circ}$ grau completo e/ou estavam cursando ou concluído o ensino superior. Eram das mais diversas localidades do Brasil, da Flórida e de Lisboa. Possuem animais de estimação 89,4\%, sendo 344 cães, 155 gatos, 86 aves e 70 outros. Afirmaram levar seus animais ao veterinário 91,2\%, sendo 12,8\% para rotina, $13,3 \%$ vacinação, $20,9 \%$ quando o animal fica doente e $53,1 \%$ devido a todos os motivos apresentados. Sobre a vermifugação, nos últimos 6 meses, 74,1\% afirmaram ter administrado algum medicamento. Além disso, 78,4\% vacinaram seus animais no último ano, sendo que $88,6 \%$ para raiva e $74,1 \%$ polivalente. Somente $28,9 \%$ afirmaram dar a vacina de raiva em campanhas do município e $36,6 \%$ dos proprietários não levam seus animais para o reforço anual da vacina polivalente. A castração $(82,4 \%)$ é o método mais utilizado para animais não terem cria. Dos cães que tem acesso à rua $(66,2 \%), 75,5 \%$ saem com guia. Foi observado que os proprietários possuem percepção sobre o assunto, e dessa forma, podem assegurar o bem estar dos animais e colaborar para a prevenção das principais zoonoses e de outras doenças, evitando riscos para a saúde pública.

PALAVRAS-CHAVE: ANIMAIS DE COMPANHIA, CÃES E GATOS, AMOSTRAGEM ONLINE, SAÚDE PÚBLICA.

AGRADECIMENTO: Departamento de Medicina Veterinária Preventiva e a Liga Acadêmica de Saúde Pública Veterinária (LASP).

ÁREA TEMÁTICA: SAÚDE PÚBLICA 